Walisongo Law Review (Walrev), Vol 2 No. 2 (2020)

DOI: 10.21580/Walrev/2020.2.2.5325

Copyright (C) 2020 Walisongo Law Review (Walrev)

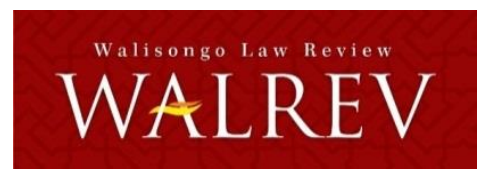

\title{
Over Capasity as an Opportunity fot the Directorate General of Correctors In Optimizing Revitalization
}

\section{Fatkhur Rokhman}

Afiliasi: Politeknik Ilmu Pemasyarakatan Cinere, Depok

Email:rohmanfatkhur95@gmail.com

\begin{abstract}
Overcapacity is a condition in which a building is overloaded. Lots of riots or problems in prisons are caused by overcapacity. Therefore it is necessary to handle and treat overcapacity in prisons which initially became a problem and a threat that could create a potential opportunity in the development and implementation of correctional revitalization. The method used in the making of this journal uses descriptive qualitative research methods. By using secondary data sources, using literature study data collection techniques, and performing data analysis techniques in the form of collecting data, reducing data, presenting data, and concluding data so that it is easy to understand. In Correctional Revitalization, the condition of overcapacity in prisons can be used as an opportunity by placing inmates who have passed the assessment to be placed in minimum security prisons to be optimized or empowered through self-supporting programs such as training in plantations, fisheries, creative crafts, animal husbandry and agriculture and for personality development such as education.
\end{abstract}

[]

Overkapasitas merupakan suatu kondisi dimana di dalam sebuah bangunan mengalami kelebihan muatan. Banyak 
sekali kejadian kerusuhan atau masalah di dalam Lapas di sebabkan karena overkapasitas. Oleh karena itu perlu adanya penanganan dan pengolahan overkapasitas dalam Lapas yang awalnya menjadi masalah dan ancaman bisa menjadikan peluang yang potensial dalam pembinaan dan pelaksanaan revitalisasi pemasyarakatan. Metode yang digunakan dalam pembuatan Jurnal ini, menggunakan metode penelitian kualitatif deskriptif. Dengan menggunakan sumber data sekunder, menggunakan teknik pengumpulan data studi pustaka, dan melakukan teknik analisis data berupa mengumpulkan data, mereduksi data, menyajikan data, dan menyimpulkan data sehingga mudah dipahami. Dalam Revitalisasi Pemasyarakatan, kondisi overkapasitas dalam Lapas bisa dimanfaatkan menjadi sebuah peluang dengan menempatkan narapidana yang telah lulus assessment untuk di tempatkan ke dalam Lapas minimum Security untuk kemudian dioptimalkan atau diberdayagunakan melalui program pembinaan kemandirian seperti pelatihan perkebunan, peikanan, kerajinan kreatif, peternakan, dan pertanian dan untuk pembinaan kepribadian seperti pendidikan.

Keywords: Overcapacity; Prison; Correctional Revitalization.

\section{Introduction}

Based on Article 1 paragraph (3) of the 1945 Constitution of the Republic of Indonesia it explains that "Indonesia is a state of law". Every person residing in the territory of Indonesia is obliged to obey the law, if they violate the law then they can be given sanctions, from mild to severe sanctions in the form of imprisonment. Criminalization is seen as the last weapon in tackling and preventing crime (Wiyanto, Roni 2012: 110). Imprisonment is in the form of limiting the freedom of movement of a convicted person by placing the person in a prison which causes the person to obey all the rules of procedure for those who have violated them (Lamintang, 1986: 58).

Almost all the existing regulations are included in the Criminal Code, all of which lead to imprisonment. Starting from the form of minor crimes to serious crimes, all of them lead to imprisonment. In fact, there are other alternative forms of punishment, such as fines, rehabilitation, city detention/house arrest, and social work. Law 
enforcers should be wiser in giving a sentence to someone who is deemed entitled to receive this light sentence, but in reality almost all crimes result in imprisonment. This is what causes prisons throughout Indonesia to experience overcapacity.

Overcapacity is a condition in which a building is overloaded. Or in this case what we associate with Lapas. Prisons that should have an ideal capacity, for example 100 people, but in reality are filled with 300 people, this is what is called overcapacity. Of course this overcapacity causes several negative effects in the guidance and security system in the prison, such as the level of security vulnerability, the level of sanitation and environmental hygiene, the health level of prisoners, the level of comfort and the sense of security in the prison will be very low.

Lots of riots or problems in prisons are caused by overcapacity. Therefore it is necessary to handle and treat overcapacity in prisons which initially became a problem and a threat that could create a potential opportunity in the development and implementation of correctional revitalization.

Even though in the midst of conditions in most prisons in Indonesia experience overcapacity, prisoners who are in their prisons are obliged to follow the rules in prisons and carry out guidance in prisons so that later they are able to realize their mistakes and can live their lives, lives and livelihoods in the community. This is in accordance with Article 1 point 3 of Law no. 12 of 1995 concerning Corrections which explains that "Penitentiary, hereinafter referred to as LAPAS, is a place to carry out the development of prisoners and Correctional Students".

The Directorate General of Corrections is exploiting the overcapacity condition of prisons in realizing Correctional Revitalization. Through the large number of prisoners in prisons, they are all empowered to the maximum extent possible by the Director General of Pas in order to form superior and advanced human beings. So that when they are free from prison, they will be able to live their life, life and livelihood in the community later. Based on the description above, the author is interested in making a journal, namely "Overcapacity as an opportunity for the Directorate General of Corrections in Optimizing Correctional Revitalization". 


\section{Research Method}

This research uses a descriptive qualitative research type that is literature study using books and other literatures as the main object (Hadi, 1995: 3). Qualitative research itself is research that produces information in the form of notes and descriptive data contained in the text under study.

The data source used is secondary data sources. Secondary data sources are sources that do not directly provide data to data collectors (Sugiyono, 2015: 137). For example, research has to go through other people or search through documents. This data is obtained using literature studies conducted on many books, laws and regulations, obtained based on notes, obtained from the internet related to research.

The data collection technique used is literature study. Literature study is a data collection method that is directed at finding data and information through photos, pictures, books, papers, documents, both regular documents and electronic documents that can support the writing process. Research results will also be more credible if they are supported by existing photographs or academic papers and art (Sugiyono, 2005: 83).

Data analysis according to Moleong is an effort made by working with data, organizing data, sorting it into manageable units, synthesizing it, looking for and finding patterns, finding what is important and what is learned, and deciding what to tell people. (Moleong, 2011: 248) According to Miles \& Huberman $(2014 ; 17)$ states that data analysis techniques in qualitative research include: Data collection, namely managing and preparing data for analysis; Data Reduction is a form of removing unnecessary information and organizing reduced data in order to provide a sharper picture of the results of the observations into themes; Data Presentation, namely presenting data in the form of brief descriptions, tables, charts, and relationships between categories. By presenting the data, the data is organized and structured so that it is easier to understand; and Conclusion Drawing, namely the withdrawal of the results from a research process. Conclusions in qualitative can answer the problem formulation formulated from the start. 


\section{Research Result}

Apart from being a place for punishment, the prison also functions to carry out a program of guidance for inmates. Where through this coaching program, prisoners are trained so that they become human beings who realize their mistakes, are able to improve themselves into something better than before, and not repeat criminal acts again. The ultimate goal of this guidance program is so that prisoners when they are free from prison, they are able to live their life, live and re-live in the community, and are able to carry out their social functions again.

The phenomenon of overcapacity that occurs in most prisons in Indonesia is a big challenge that must be faced by the Directorate General of Pas. How can not one prison, which should have a capacity for example 100 prisoners, is even filled with up to 300 prisoners, of course this has resulted in the prison being not ideal in implementing the guidance program.

There have been many incidents of riots in prisons that have experienced overcapacity, such as the riots at the Tanjung Gusta Prison in Medan, the Sialang Butut Prison in Pekanbaru, the Kerobokan Bali Prison, and other prisons. The condition of the number of assisted residents who are not ideal with spacious rooms is prone to causing individual conflicts that lead to fights, although peace usually occurs quickly. Of course this is not a good thing if events like this happen continuously.

Facing the phenomenon of overcapacity in prisons, which is mostly experienced in Indonesia, makes the Directorate General of Pas take steps as a solution in overcoming this overcapacity. One of them is by revitalizing prisons and establishing new prisons in support of revitalizing these prisons. Instead of seeing overcapacity as a problem, in correctional revitalization has its own view by empowering this overcapacity to carry out a more maximal coaching in order to realize superior and advanced human resources. In correctional revitalization, overcapacity, which was initially a problem, is changed and managed into opportunities and strengths.

The Director General of Corrections, Sri Puguh Budi Utami, explained that Correctional Revitalization is an effort to optimize the administration of correctional facilities as a form of treatment of 
prisoners, prisoners and clients as well as protection of ownership rights to evidence so that it can make it easier for organizations to take policy steps. Revitalization of the Correctional System as part of the Criminal Justice System is interpreted as an effort to re-establish the "important function" of correctional facilities as bridging legal gaps or as a bridge between the realm of Law in the book and the realm of Law in action. Correctional is said to be a bridge because socialization is positioned as a social institution that has a function as a link between two very different sides of a situation, namely to return the offender who is subject to forced attempts to a free society.

The revitalization approach must also be able to recognize and utilize its potential. Revitalization itself is not something that is oriented only to solving problems, but also must be complemented by projections of increased efficiency. The process of revitalizing the correctional system in the future must also determine the scale in order to get the right target. Revitalization of the Correctional System is expected to cover improvements in material aspects and nonmaterial aspects. To carry out revitalization, it is necessary to involve all components, including government, private sector, and society.

The revitalization implementation applies a competency-based coaching model. The coaching program model aims at efforts to prepare and produce Correctional Assistance Citizens who are able to integrate themselves into the community, have character and are competent to provide a driving force for development activities in various sectors. Corrections will be able to prepare independent Correctional Assistance Citizens who are ready to work professionally and capable of entrepreneurship to drive national development as a successful achievement of the implementation of the Correctional System. In addition, the coaching model in the correctional system revitalization program prioritizes adjustments to correctional management governance by focusing on indicators of changes in the behavior of prisoners in a better way in thinking, acting or behaving. This indicator will be one of the components in the successful implementation of the coaching program. By prioritizing the principle of "Changing the behavior of prisoners, without being based on and limited by time", pragmatically the concept of guidance that will be given to prisoners is not fixated on the process time staging guidelines based on the coaching pattern but focuses on the results of measuring 
indicators of prisoners' behavior change that arise consistently. The measurable achievement of correctional administration based on the revitalization program is expected to encourage the achievement of the Main Performance Indicators (IKU) of correctional administration in Indonesia, namely:

a. Increasing the quality of correctional administration;

b. Increased productivity of prisoners, children and correctional clients towards independent humans;

c. Increased legal compliance of former prisoners, children and correctional clients (decreasing number of recidivists).

The correctional process based on the revitalization program starts when a detainee is placed in a State Detention Center for the purposes of investigation, prosecution and examination in court. The programs provided are in the form of personality service programs and legal services. For those who have been convicted by a judge and have obtained permanent legal force. Before being placed, an assessment is carried out to measure the level of risk of the prisoner whether it is included in the high risk/or non high risk category. For those categorized as high risk, their placement is in a High Risk Prison. Meanwhile, for all prisoners with the non-high risk category, the placement will be carried out at the Maximum Security Penitentiary.

Various treatment program guidance will be provided to the prisoners and behavior development will be monitored by the Correctional Institution through a behavior assessment instrument. Evaluation of the implementation of program provision is carried out periodically to measure changes in the behavior of prisoners. Those who have shown changes in behavior according to predetermined indicators will be transferred from the Maximum Security Penitentiary to the Medium Security Penitentiary.

At the Medium Security Penitentiary, inmates will get a skills development program that leads to vocational knowledge in order to improve the soft skills and hard skills of prisoners in producing a product/service. If the prisoners have met the assessment requirements based on the indicators of the success of the implementation of the program at the Medium Security Penitentiary, 
then the prisoners will then be transferred to the Minimum Security Penitentiary.

In the Minimum Security Penitentiary, the development program for prisoners is expected to be able to encourage the prisoners' ability to independently produce industrial-scale goods / services. It is also at this time that prisoners receive a reintegration program. It is in this minimum prison that the overcapacity that occurs in most prisons in Indonesia is converted into an opportunity and strength. With this large number of human resources, the Directorate General of Pas is expected to be able to manage these human resources into superior and advanced human beings. The following is the Correctional Revitalization scheme in managing overcrowding in prisons.

In this scheme it is explained that the condition of overcapacity in prisons can be used as an opportunity by placing inmates who have passed the assessment to be placed in minimum security prisons to be optimized or empowered through self-reliance development programs such as training in plantations, fisheries, creative crafts, animal husbandry, and agriculture. And for personality development such as education. Where the ultimate goal of this revitalization process is to:
a. Establish welfare for WBP;
b. WBP becomes superior HR;
c. Become a national priority commodity;
d. Take an active role in the national defense program; and
e. Generate Non-Tax State Income (PNBP).

\section{Conclusion}

Correctional revitalization has made overcapacity which was originally a problem, changed and managed into opportunities and strengths. The coaching model in the correctional system revitalization program prioritizes adjustments to correctional management governance by focusing on indicators of changes in the behavior of prisoners towards a better way of thinking, acting or behaving.

The condition of overcapacity in prisons can be used as an opportunity by placing inmates who have passed the assessment to be placed in minimum security prisons for later optimization or 
empowerment through self-reliance development programs such as training in plantations, fisheries, creative crafts, animal husbandry, agriculture, and for personality development such as education. [w]

\section{Reference}

Hadi. 1995. Statistik. Jilid II. Yogyakarta; Andi Offset.

Lamintang. 1986. Hukum Panitensir Indonesia. Bandung; Aremico.

Miles, M.B, Huberman, A.M, and Saldana, J. 2014. Qualitative Data Analysis, A Methods Sourceboook, Edition 3. USA; Sage Publications. Terjemahan TjetjepRohindi Rohidi.

Moleong, L.J. 2011. Metode Penelitian Kualitatif Edisi Revisi. Bandung; PT Remaja Rosdakarya.

Saefulloh, Anang. 2018. Rancangan Naskah Akademik Revitalisasi Sistem Pemasyarakatan Sebagai Bagian Dari Sistem Peradilan Pidana. Jakarta; Direktorat Jendral Pemasyarakatan.

Sugiyono. 2005. Metode Penelitian Kombinasi (Mix Methods). Bandung; Alfabeta. 2015. Sugiyono. Metode Penelitian Bisnis. Bandung; Alfabeta.

Wiyanto, Roni. 2012. Asas-asas Hukum Pidana. Bandung; CV. Mandar Maju.

Angkasa. 2010. Over Capasity Narapidana Di Lembaga Pemasyarakatan, Faktor Penyebab, Implikasi Negatif, Serta Solusi Dalam Upaya Optimalisasi Pembinaan Narapidana. Universitas Jendral Soedirman; Fakultas Hukum.

Martina, L. 2009. Over Kapasitas Di Lembaga Pemasyarakatan Faktor Penyebab dan Upaya Penanggulangannya di Lapas Kelas 1 Tanjung Gusta Medan. Universitas Sumatra Utara; Fakultas Hukum. 
Sandra, Vanessa. 2016. Pengaruh Over Capacit Lembaga Pemasyarakatan Terhadap Kinerja Pemasyarakatan Di Lapas Kelas IIB Sleman. Atma Jaya Yogyakarta; Fakultas Hukum.

Sofa, A. 2017. Dampak Negatif dan Upaya Penyelesaian Over Kapasitas di Lapas Kelas I Malang. Universitas Muhammadiyah Malang; Fakultas Hukum.

Selly, D. Dampak Kelebihan Kapasitas Warga Binaan Di Lembaga Pemasyarakatan Kelas IIA Pekanbaru Dikaitkan Pemenuhan Hak-Hak Warga Binaan Berdasarkan Peraturan Menteri Hukum Dan Hak Asasi Manusia Republik Indonesia Nomor M.HH-07. OT. 01. O3 Tahun 2011. Universitas Riau; Fakultas Hukum. 2016.

Septiawan, Yudha Nugraha. "Analysis of the Causes of Narcotics Recidivities in Class IIa Prisons in Bogor." Walisongo Law Review (Walrev) 2.1 (2020): 67-84.

Undang-Undang Dasar RI Tahun 1945

Undang- Undang No. 12 Tahun 1995 Tentang Pemasyarakatan

Zakaria, Moch Subhan. "Implementation of the Methadone Maintenance Therapy Program for Highrisk Drug Prisoners." Walisongo Law Review (Walrev) 2.1 (2020): 99111. 